\title{
Essential Oil of Javanese Turmeric (Curcuma xanthorrhiza, Roxb) Decrease Level of LDL-Cholesterol and Body Weight in Rats
}

\author{
Endang Darmawan ${ }^{1 *}$, Suwijiyo Pramono ${ }^{2}$ \\ ${ }^{1}$ Faculty of Pharmacy, Ahmad Dahlan University, Yogyakarta, Indonesia \\ ${ }^{2}$ Faculty of Pharmacy, Gadjah Mada University, Yogyakarta, Indonesia
}

\begin{abstract}
The aim of the present study was to investigate the effect of the essential oil of Javanese turmeric (Curcuma xanthorrhiza, Roxb) on level of low density lipoproteincholesterol (LDL-C) and body weight in rats. The groups were induced by high fat diet for 30 days to produce hyperlipidemia. The rats were treated with essential oil $25 \mathrm{mg} / \mathrm{kgBW}$ and simvastatin $25 \mathrm{~kg} / \mathrm{kgBW}$ for 30 days. The LDL-C and body weight were measured on day one before treatment, and on day thirthy of the treatment. The results showed that the essential oil decreased the level of LDL-C and body weight in rats.
\end{abstract}

Keywords: Javanese turmeric, Curcuma xanthorrhiza, essential oil, lipoprotein, simvastatin

\section{INTRODUCTION}

Coronary heart disease is a common term for the buildup of plaque in the heart's arteries that could lead to heart attack. The traditional risk factors for coronary artery disease are high LDL-cholesterol, low HDLcholesterol, high blood pressure, family history, diabetes, smoking, being postmenopausal for women and being older than 45 for men. Obesity may also be a risk factor (Wunsch, 1998). Treatment of CDH by include medication, bypass surgery, and minimally invasive methods. A first line treatment to lower high cholesterol in patients with or at risk for coronary artery disease is by simvastatin medication. Simvastatins help relax blood vessels, lowering blood pressure and lowering cholesterol. But like all medication, statins have also many side effects. Otherwise, it is necessary to find out the safe alternative medicine from natural herbal to lowering cholesterol.

Javanese turmeric is the rhizome of $C$. xanthorrhiza Roxb and is used as a food spice, and a preservative and colouring agent in Indonesia and South East Asia. Javanese turmeric contains of curcuminoids and essential oil (Yasni, 1994). Curcuminoids, such as curcumin, demethoxycurcumin and bisdemethoxy curcumin, are yellowish turmeric pigments and have antioxidative, anticarcinogenic, anti-inflammatory, antihepatotoxic and hypocholesterolemic activities (Nishiyama, et al., 2005). However, little attention has been paid to its hypoliidemia effect of the essential oil of $C$. xanthorrhiza. This study was intended to investigate the effect of dietary supplementary of essential oil of $C$. xanthorrhiza on LDL-cholesterol level and body weight in rats.

\section{MATERIALS AND METHODS}

Isolation of the essential oil of $C$. xanthorrhiza

The essential oil was prepared from $C$. xanthorrhiza rhizome by water and steam distillation.The oil was collected in a sterile flash to be stored at refrigeration before application.

$\overline{\text { *Corresponding author e-mail: enddarmawan@yahoo.com }}$ 


\section{The hypolipidemia of the essential oil of C. xanthorrhiza}

Twenty rats were divided into five groups, each consisting of 5 animals. Group I was given basal diet and solvent control (CMC $0.5 \%$ ). Group II was given high-lipid diet for 60 days. Group III as the positive control group was given high-lipid diet for 30 days and simvastatin $25 \mathrm{mg} / \mathrm{kgBW} 30$ days. Group IV was given high-lipid diet 30 days and treated by essential oil at dose $25 \mathrm{mg} / \mathrm{kgBW}$ for 30 days.

The LDL-cholesterol serum level at day 0,30 and 60 was measured. Serum samples were thawed and the concentrations of LDLcholesterol, were determined using a spectrophotometer and commercial enzymatic kits.

\section{Body weight Measurement}

The body weight of rats was measured every week from day 1 to day 60 .

\section{Data Analysis}

The change of LDL-cholesterol concentrations and body weight were analyzed statistically using two-way ANOVA on 95\% confidence level.

\section{RESULTS AND DISCUSSION}

Tabel 1 show that the essential oil decreased the LDL-cholesterol level of rats after treatment for 30 days.
The body weight of rats in all groups intended to increase each day (Table 2). But, the treatment both of simvastatin and the essential oil slightly decreased the body weight of rats. Awalin (1996) reported that the essential oil of C. xanthorrhiza decrease the appetite of rats. Curcumin is the main phenolic compound of Javanese turmeric that has an antioxidant effect. Instead of antioxidant effects, curcumin has a hypocholesterolemic effect. It can reduce the concentrations of plasma low-density lipoproteins and very low-density lipoproteins and liver total cholesterol (Kamal-Eldin, et al., 2000). Yasni, et al. (1994) reported $C$. xanthorrhiza contains an active compound other than the curcuminoids that can modify the metabolism of lipids and lipoproteins and even liver fatty acid synthase activity. In another experiment they identified alpha-curcumene as the major component (approximately 65\%) of Curcoma xanthorrhiza essential oil (Yasni, et al., 1994). Addition of $0.02 \%$ Curcoma xanthorrhiza essential oils prepared by steam distillation to a purified diet resulted in a lower hepatic triglyceride concentration in rats, whereas addition of the hexane-soluble fraction $(0.5 \%)$ resulted in a lower concentration of serum, as well as liver triglycerides. Rats fed the essential oil had a lower hepatic fatty acid synthase activity. These studies, therefore, indicate that the essential oil of $C$. xanthorrhiza may has the hypolipidemia effect, further studies should be perfomed.

Tabel I. The change of LDL-cholesterol serum level (\%) after dietary of high-lipid and treatment of essential oil of $C$. xanthorrhiza 30 days

\begin{tabular}{ccc}
\hline Group & The change in LDL level (\%) \\
\hline I & $0.25 \pm 12.92$ \\
II & $30.25 \pm 8.74$ \\
III & $-|4.3| \pm \mid 7.3 I^{*}$ \\
IV & $-10.38 \pm\left. 5.4\right|^{*}$ \\
\hline Note: & - means the concentration decreased compared to concentration at day 30 \\
& $*$ means significantly different on $95 \%$ confidence level
\end{tabular}


Tabel 2. The change in body weight of rats after dietary of high-lipid and treatment of essential oil of C. xanthorrhiza 30 days

\begin{tabular}{cc}
\hline Group & The change of body weight (\%) \\
\hline I & $2.82 \pm 0.53$ \\
II & $1.74 \pm 0.78$ \\
III & $1.90 \pm 0.40$ \\
IV & $1.82 \pm 0.33$ \\
\hline
\end{tabular}

\section{REFERENCES}

Awalin, N., 1999, Minyak Atsiti Rimpang Temulawak, Pengaruhnya Terhadap Kenaikan Berat badan Tikus Putih Jantan dan Analisis Kandungan Kimianya, Essay, Universitas Gadjah Mada, Yogyakarta.

Kamal-Eldin, A., Frank, J., Razdan, A., Tengblad, S., Basu, S. and Vessby, B., 2000, Effects of Dietary Phenolic Compounds on Tocopherol, Cholesterol, and Fatty Acids in Rats, Lipids, 35(4), 427-435.

Nishiyama, T., Mae, T., Kishida, H., Tsukagawa, M., Mimaki, Y., Kuroda, M., et al, 2005, Curcuminoids and sesquiterpenoids in Turmeric (Curcuma longa L.) Suppress an Increase in Blood Glucose Level in Type 2 Diabetic KK-Ay Mice, J. Agric. Food Chem., 53(4), 959-963.
Wunsch H., 1998, Issue of Lower for LDLCholesterol Unresolved, Lancet, 35 I (9III), I 257.

Yasni, S., Imaizumi, K., Nakamura, M., Aimoto, J. and Sugano, M., 1993, Effects of Curcuma xanthorrhiza Roxb. and Curcuminoids on the Level of Serum and Liver Lipids, Serum Apolipoprotein A-I and Lipogenic Enzymes in Rats, Food Chem. Toxicol., 3 I (3),2 I3-2 I8.

Yasni, S., Imaizumi, K., Sin, K., Sugano, M., Nonaka, G. and Sidik., 1994, Identification of Active Principle Inessential Oils and Hexane-Soluble Fractions of Curcuma xanthorrhiza Roxb. Showing Triglyceride Lowering Action in Rats, Food Chem. Toxicol., 32(3), 273-278. 